\title{
Performative and economic analysis on local duck farming in Central Java - Indonesia
}

\author{
I. Ismoyowati 1,*, B. C. Pratama ${ }^{2}$ and M. N. Innayah' \\ ${ }^{1}$ Faculty of Animal Science, Universitas Jenderal Soedirman, \\ Jl. Dr. Suparno No.60, Karangwangkal, Purwokerto 53122 - Indonesia \\ ${ }^{2}$ Faculty of Economic and Business, Universitas Muhammadiyah Purwokerto, \\ Jl. KH. Ahmad Dahlan, Purwokerto 53182 - Indonesia \\ Corresponding E-mail: ismoyowati@unsoed.ac.id
}

Received February 21, 2020; Accepted June 16, 2020

\begin{abstract}
ABSTRAK
Jawa Tengah merupakan daerah utama yang menghasilkan produksi telur itik kedua terbesar seIndonesia atau sebesar $13.55 \%$ dari jumlah produksi telur nasional. Oleh karena itu, usaha peternakan itik di Jawa Tengah memerlukan evaluasi ekonomi untuk mengidentifikasi keberhasilan usaha. Analisis ekonomi dalam suatu usaha akan memperbarui statistik terkini tentang biaya produksi, output, dan profitabilitas. Penelitian ini bertujuan untuk menilai analisis usaha peternakan itik petelur, yang meliputi: biaya produksi marjinal, total pendapatan bersih dan rasio input-output produksi telur itik di berbagai daerah di Jawa Tengah, Indonesia. Penelitian dilakukan dengan metode survei menggunakan multi-stage sampling dengan melibatkan 120 peternak itik dari Kabupaten Tegal, Brebes, dan Pemalang. Setiap kabupaten diambil 40 peternakan sebagai responden secara purposive random sampling dengan kriteria jumlah peternak yang memiliki populasi itik minimum 100 ekor dan periode produksi umur 8-12 bulan. Alat analisis yang digunakan meliputi statistik deskriptif dan farm budget. Penelitian ini mengungkapkan bahwa peternak itik mengeluarkan biaya besar untuk memperoleh input produksi, terutama dari pakan. Ketiga kabupaten menunjukkan pengembalian atau return positif berdasarkan estimasi rasio input-output (keuntungan marginal), masing-masing sebesar 1: 1.382, 1: 1.658, dan 1: 1.433 masing-masing untuk Tegal, Brebes, dan Pemalang. Kesimpulan penelitian adalah kinerja peternakan itik di Jawa Tengah masih menguntungkan meskipun pada industry peternakan rakyat (smallholders duck farm industry), dengan keuntungan yang paling tinggi diperoleh peternak di Kabupaten Brebes.
\end{abstract}

Kata kunci : biaya produksi, output, peternakan itik, profitabilitas

\begin{abstract}
Central Java is the region that produces the second largest duck egg production in Indonesia or reaches $13.55 \%$ of the total national duck egg production. Therefore, duck farming in Central Java requires an economic evaluation to identify the success of the business. The economic analysis in the duck farm industry will update the latest statistics on production costs, outputs and profitability. This study aims to assess the analysis of laying duck business, which includes: marginal production costs, total net income and input-output ratio of duck egg production in various regions in Central Java, Indonesia. The study was conducted using a survey method using multi-stage sampling involving 120 duck farmers from the regency of Tegal, Brebes, and Pemalang. Each district was taken 40 farms as
\end{abstract}


respondents by purposive random sampling with criteria for the number of breeders who had a minimum duck population of 100 ducks and a production period of 8-12 months. The analytical tools used include descriptive statistics and farm budgetary analysis. This study showed that duck breeders incur large costs to obtain production inputs, especially from feed aspects. Although three regencies reported profit based on the estimated input-output ratios, it is only a marginal profit that amounted to1: 1.382, 1:1.658, and 1:1.433 in Tegal, Brebes, and Pemalang, respectively. The conclusion of the study is the performance of duck farms in Central Java are still profitable even in the smallholder duck farm industry, with the highest profits obtained by farmers in Brebes Regency.

\section{Keywords: output, production cost, profitability incurs, smallholders duck farm industry}

\section{INTRODUCTION}

The poultry industry plays an important role in the Indonesian economy in providing affordable sources of protein for Indonesian citizens. This is indicated by the large contribution of the Agriculture sector in general and in particular the livestock Subsector to Indonesia's GDP during the period of 20102016.The Agriculture sector provided the secondlargest contribution to Indonesia's GDP in the 2010-2016 period (Directorate General of Animal Husbandry and Health, 2017).

Central Java Province is the main area producing the second largest duck egg production in Indonesia, after West Java Province, or reaches $13.55 \%$ of the total national duck egg production (Directorate General of Animal Husbandry and Health, 2017). Therefore, meeting the demand of national duck eggs is very dependent on the production of ducks from farmers in Central Java. In order to realize those ideals, smallholders duck farm industry in Central Java must be able to produce optimally and be able to maintain a level of profitability so that it can continue to operate sustainable and also provide welfare for the farmers.

However, smallholders duck farm industry in Central Java, like most poultry industries, faces potential issues that cover access to production, sustainability and inefficient way navigate resources (Shamsudin, 2013). The margins between production and sales costs are small and force farmers receive a small profit. This is similar to the broiler industry, where the Net of return in poultry production is not promising and then limits the inflow of new investment (Rahman, 2003). Higher feed costs are the contributing factor to low performance in poultry industry which is closely dependent on trends in prices of the main feed compositions (Chanjula et al., 2002; Elsedig et al., 2015). The extensive duck rearing system is very dependent on the availability of natural food in post-harvest rice fields, such as grains of rice, snails, small frogs, grasshoppers, and insects. Therefore, costs incurred for feed also depend very much on natural conditions, because when natural feed conditions are not available, it will result in inflated feed costs. The availability of different feeds will affect the pattern of feed composition provided (Ismoyowati and Suswoyo, 2011). Therefore, to ensure a sustainable supply of duck eggs and be able to meet consumer demand in Indonesia, the factors that increase the profitability of the duck industry must be examined.

The feed cost for duck egg production constituted $90 \%$ of the total variable cost, while other costs for employees, vitamin, and others were altogether below $10 \%$. It is crucial to investigate the key factors to improve the profitability of the duck industry in order to guarantee the perpetual and sustainable supply of duck eggs in Indonesia. The correlation between duck egg performance and maximum profit was indicative of the important massive investment and high feed cost to reach optimum performance and the breeders' interest (Tangendjaja, 2013). Regarding the potential unstable profit due to high production cost in duck industry, it is important to conduct a cost-benefit analysis to varied performance indicators for new stakeholders and policy makers in Indonesia.

Feed cost takes up $>70 \%$ of the total cost of poultry production cost. Production input (total physical items and cost) and farm size contribute to inefficient poultry production. This situation is a seemingly potential threat to low-capital smallscale farmers. Furthermore, other issues linger in poultry production and escalate the pressure on current farms to compete (Adepoju, 2008). Some common issues in poultry are high feed price and other mitigation costs for diseases. One solution is applying contract farming to relieve the risk and generate higher potential profits for the small 
scale farmers (Nguyen et al., 2011). Lacking strong collateral security and low risk-bearing ability has made the small-scale farmers vulnerable to financial support. Even so, over half of agricultural productions are derived from these agriculture-dependent farmers (Patil et al., 2016). The poultry industry in Mirpur using economic analysis also was investigated that the production costs and benefits were used to analyze the relationship between resources and outputs. The result revealed that the high production cost and lower profit forced several commercial farms in Mirpur area to close down (Ahmad et al., 2008). Therefore, it is important to give more attention to a small scale farms industry where they received marginal income. The purpose of this study was to determine the socioeconomic characteristics of smallholders' duck farm industry in Central Java, its production performance, selling price of duck eggs, laying duck business cost, and input-output ratio.

\section{MATERIALS AND METHODS}

\section{Study Area and Source of Data}

This study emphasized on duck farms in Central Java, Indonesia, where duck farming according to data production availability - is extensively distributed in a diverse scale and modes of operation according. The area of study included Tegal, Brebes, and Pemalang Regency. This study used interviews and questionnaire (pilot-tested) to collect the primary data, and other measures to collect secondary information.

Sampling method

A multi-stage sampling was conducted to obtain the most representative population. The first stage is to determine the area of Central Java as a population, with 3 municipalities/regencies with the largest population of ducks namely Tegal, Brebes, and Pemalang.

The respondents in Tegal Regency are the Kemiri Barat duck group of farmers with 26 members and the Satelit Sejahtera farmers with 39 members. While, the respondents in Pemalang Regency are the Bulusari livestock group farmers with 23 members and Klareyan with 15 members. For Brebes Regency, the respondents are of farmers of Maju Jaya group with 22 members and the KTT Sumber Pangan with a total of 26 members. Each regency was taken 40 farmers as respondents by purposive random sampling with criteria for the number of farmers who had a minimum duck population of 100 ducks, production period of 8-12 months. On the second stage, duck farmers from small, medium and large farming scale were selected as the population. At last, 120 duck farmers were selected using a simple random sampling technique as the respondents for the interviews and survey.

Analytical techniques

The obtained data were subject to descriptive statistics and simple economic analysis. Descriptive statistics presented data in graphs and figures to provide a numerical summary (Jaggi, 2012) which included farmer's age, education background, farming experiences, business scale and capital sources. Meanwhile, economic analysis may differ in complexity depending on farming commodity and technology (Heady and Dhillon, 1988). The present study applied farm budgetary techniques to calculate economic indicators, including fixed cost, variable cost, the net return, and input-output ratio. Farm budgetary techniques include calculation of farm budget plan in monetary terms, i.e. by the estimation of receipts, expenses and net income, is called farm budgeting. In other words, farm budgeting is a process of estimating costs, returns and net profit of a farm.

Production function equation:

$$
\mathrm{Q}=\mathrm{f}(\mathrm{Cv}, \mathrm{Cf})
$$

where

$\mathrm{Q}=$ the quantity of output

$\mathrm{Cv}=$ the quantity of variable inputs used (including feed costs, vaccine, feed additive)

$\mathrm{Cf}=$ the quantity of fixed inputs employed (including, employee costs and household costs)

The production cost is calculated based on the variable inputs and fixed inputs from the interview. Feed conversion ratio is among the key rations in animal production; therefore, farmers conduct an efficient farming to lower the feed conversion ratio.

Feed Conversion Rate (FCR) in duck population each farmer equation:

$\mathrm{FCR}=[$ Total Feed $(\mathrm{kg}) /$ Total Eggs $(\mathrm{kg})]$

The formula showed that if the ratio is 2 , the management and technology converts $2 \mathrm{~kg}$ of feed to 1 egg which is indicative of inefficient duck egg production.

\section{RESULTS AND DISCUSSION}

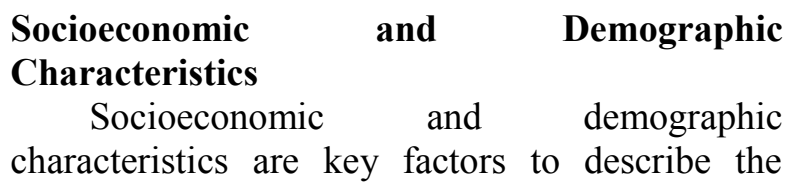


current social status of duck farms ownership and management in Central Java, Indonesia. These factors are farmer's age, education background, farming experiences, business scale and capital source. Regarding age, $35 \%$ of farmers are 51 years and above, and $16.67 \%$ are young farmers
(Table 1).

As a duck egg production needs some capital and experiences, emerging farmers may hesitate to participate in the smallholders duck farm industry; therefore, there is only a fraction of young farmers involved in total duck farms.

Table 1. Socioeconomic Characteristics of Duck farmers in Central Java, Indonesia

\begin{tabular}{|c|c|c|}
\hline Category & $\begin{array}{l}\text { Number of } \\
\text { Respondents } \\
\text { (people) }\end{array}$ & $\begin{array}{c}\text { Percentage } \\
(\%)\end{array}$ \\
\hline \multicolumn{3}{|l|}{ Farmer's Age (years old) } \\
\hline $20-30$ & 20 & 16.67 \\
\hline $31-40$ & 32 & 26.67 \\
\hline $41-50$ & 26 & 21.66 \\
\hline 51 and above & 42 & 35.00 \\
\hline Total & 120 & 100.00 \\
\hline \multicolumn{3}{|l|}{ Education Level } \\
\hline Did not graduate from Elementary School & 30 & 25.00 \\
\hline Elementary School & 36 & 30.00 \\
\hline Junior High School & 22 & 18.33 \\
\hline Senior High School & 24 & 20.00 \\
\hline University & 8 & 6.67 \\
\hline Total & 120 & 100.00 \\
\hline \multicolumn{3}{|l|}{ Farming Experiences } \\
\hline$<1$ year & 6 & 5.00 \\
\hline $1-2$ years & 4 & 3.33 \\
\hline $2-3$ years & 8 & 6.67 \\
\hline $3-4$ years & 4 & 3.33 \\
\hline 5 years or above & 98 & 81.67 \\
\hline Total & 120 & 100.00 \\
\hline \multicolumn{3}{|l|}{ Scale of Business (ducks) } \\
\hline Small Scale (100-500) & 66 & 55.00 \\
\hline Medium Scale $(>500-1000)$ & 46 & 38.33 \\
\hline Large Scale $(>1000)$ & 8 & 6.67 \\
\hline Total & 120 & 100.00 \\
\hline \multicolumn{3}{|l|}{ Source of Capital } \\
\hline Own Capital & 98 & 81.67 \\
\hline Loan from Banks & 14 & 11.66 \\
\hline Others & 8 & 6.67 \\
\hline Total & 120 & 100.00 \\
\hline
\end{tabular}


Regarding education background, most farmers $(38.33 \%)$ are high school graduates, $30 \%$ are primary school graduates, $25 \%$ are primary school dropouts, and only $6.67 \%$ hold bachelor degree. Regarding farming experience, $81.67 \%$ of the farmers have been involved in duck egg production for over 5 years, while only $19.33 \%$ have $0-5$ years of experience. The entrepreneurship training positively affected management practices (Ezeibe et al., 2014).Three categories of duck farming operations based on the resource management, productivity, and sustainability, the operators are small scale $(<500$ ducks), medium-scale (500- 1000 ducks) and large scale ( $>1000$ ducks). This study reported that $93.33 \%$ farmers belong to small and medium scale categories, and the rest is the large scale farmers, this shows that the duck farming business is still a smallholder farm industry (Table 1). This will affect productivity since there are no economies of scale in small operations. Similarly, (Farooq et al., 2001; Ahmad et al., 2008) reported that most farmers are small and medium scale operators.

Monetary credit enables farmers to buy adequate inputs and to practice efficient performance to gain optimum revenue and. The present study indicated that $81.67 \%$ of the duck farmers' self-sustain the expenses, while $11.66 \%$ are dependent on loans from different institutions, and $6.67 \%$ from other sources (Table 1).

\section{Duck Production and Price}

This study reported a slight difference in total egg production across regions (Table 2). Tegal Regency is the highest in terms of average number of ducks amounted to 715 ducks. While, Brebes and Pemalang Regencies are at lower average number of ducks at 495 and 290 ducks, respectively. However, the average selling price of duck egg across regions are also varied at IDR 1,525, IDR 1,687, IDR 1,300 for Tegal, Brebes, and Pemalang, respectively. Tegal Regency produced the highest number egg production, with the average production of duck eggs per month amounted to 13,771 eggs (936.64 kg). While Brebes and Pemalang Regencies are at lower average production of duck eggs per month amounted to $9,850(643.20 \mathrm{~kg})$ and 6,785 eggs $(459.50 \mathrm{~kg})$, respectively. On the other hand, the average feed per duck among regions are varying at $5.16 \mathrm{~kg}, 5.29 \mathrm{~kg}$, and $5.73 \mathrm{~kg}$ for Tegal, Brebes, and Pemalang, respectively. Therefore, Brebes Regency confirms the highest FCR of 4.01; indicative of ratio $4.01 \mathrm{~kg}$ feed for $1 \mathrm{~kg}$ egg. An accurate FCR data across regions is important to calculate feed consumption each duck (Sahzadi et al., 2006).

\section{Cost of Production}

The components of fixed cost are the cost of duck and farm equipment, could be seen in Table 3. Meanwhile, the components of variable cost are employee cost, feed cost, and feed additive (vitamins, probiotics, etc.). As expected, feed cost account for the largest proportion of total variable costs (Table 4), followed by labor cost, and the least is a feed additive (vitamins, probiotics, etc.). The output level is directly associated with a total variable cost that is particular to business and varied in scales. These variable costs are mostly present as working capital that applies to the production cycle (García-Teruel, and MartínezSolano, 2007). In general, the total variable costs vary across regions in Central Java, Indonesia; Tegal Regency with the biggest cost was having highest average production of duck eggs (Table 2) compared to other regions. Meanwhile, Pemalang Regency with the smallest cost result in less amount of duck egg production. Therefore,

Table 2. Production Background and Average Price

\begin{tabular}{lrrr}
\hline \multicolumn{1}{c}{ Variables } & Tegal & Brebes & Pemalang \\
\hline Average Number of Ducks & 715 & 495 & 290 \\
Average Selling Price of Eggs (IDR/egg) & 1,525 & 1,687 & 1,300 \\
Average Feed per Duck (kg/month) & 5.16 & 5.29 & 5.73 \\
Average Production of Duck eggs (eggs/month/farmer) & 13,771 & 9,850 & 6,785 \\
Average Production of Duck eggs (kg/month/farmer) & 936.64 & 643.20 & 459.50 \\
Feed Conversion Rate & 3.87 & 4.01 & 3.69 \\
\hline
\end{tabular}


Table 3. A Fixed Cost of Duck Production in Central Java, Indonesia

\begin{tabular}{lrrr}
\hline \multicolumn{1}{c}{ Fixed Cost } & \multicolumn{1}{c}{ Tegal } & Brebes & Pemalang \\
\hline Monthly Average Cost per Duck (IDR) & 60,600 & 51,725 & 53,200 \\
Monthly Farm Equipment (IDR) & $1,339,000$ & 360,000 & 250,000 \\
Total Fixed Cost (IDR & $1,399,600$ & 411,725 & 303,200 \\
\hline
\end{tabular}

Table 4. Variable Cost of Duck Production in Central Java, Indonesia

\begin{tabular}{lrrr}
\hline \multicolumn{1}{c}{ Variable Cost } & \multicolumn{1}{c}{ Tegal } & \multicolumn{1}{c}{ Brebes } & \multicolumn{1}{c}{ Pemalang } \\
\hline Monthly Average Cost of Employees (IDR) & 325,000 & 577,500 & 0 \\
$\begin{array}{l}\text { Monthly Average Feed Cost (IDR) } \\
\text { Monthly Average Feed additive (vitamins, probiotics, }\end{array}$ & $14,886,675$ & $9,267,225$ & $6,132,450$ \\
etc.) cost (IDR) & 22,950 & 58,400 & 21,000 \\
Total Variable Cost (IDR) & $15,234,625$ & $9,903,125$ & $6,153,450$ \\
\hline
\end{tabular}

geography and socio-economy are the key factors to cost variations across areas of duck egg production.

\section{Net Returns to Duck Egg Producers}

The net returns for Pemalang Regency is the lowest compared to Brebes and Tegal Regency (Table 5). This is because, in terms of quantity of duck egg sold, Pemalang Regency was the least while Brebes and Tegal Regencies were higher. Regarding selling price, Pemalang Regency was the lowest while Brebes and Tegal Regencies were higher. On the other hand, net returns for all of the regencies are still competitive; selling price unit remains higher than the production cost unit. It indicated that farms in Tegal, Brebes, and Pemalang can better manage their cash flows in annual production cycles. Despite the high selling price per unit of duck egg, it is only marginally higher than that in Tegal, Brebes, and Pemalang Regencies. Accordingly, the production scale economy is the key factor to gain a high net return in these areas.

\section{Revenue Cost Ratio}

The input-output ratio is the parameter of investment return and the assessment point of the farm business efficiency. The concept of investments is used to express the investment in the form of pullet duck that is raised and later will bring returns in the form of egg productions. The ratio is obtained from the output (revenue) divided by the input (total cost). This study reported that the ratio of the duck industry in Central Java, Indonesia is slightly similar. This ratio indicates total input (in IDR) invested in duck egg production that would earn revenue or output in Rupiah (IDR). Table 6 showed regarding ratio of investment return, Tegal Regency generated the least, while Brebes Regency obtained the highest. An important finding in this study revealed that Tegal Regency obtained the highest value, but Brebes gained the highest ratio of investment return. Accordingly, Tegal Regency had the highest net return, but Brebes Regency is more efficient than Tegal Regency. Similarly, previous studies reported that the highest earning farms may not gain the highest investment return (Khair, 2002; Ahmad et al., 2008; Abdurofi et al., 2017). The other studies report that duck farmers have not all conducted business activities efficiently with an average value of technical efficiency of 0.9981 and the return to scale of duck business is still low (1.0868). Low production efficiency due to the scale of the number of ducks, feeding and use of technology is 
Table 5. The Net Return to Duck Egg Production in Central Java, Indonesia

\begin{tabular}{lrrr}
\hline \multicolumn{1}{c}{ Items } & \multicolumn{1}{c}{ Tegal } & \multicolumn{1}{c}{ Brebes } & Pemalang \\
\hline The average egg sold (per month) & 13,805 & 9,734 & 6,786 \\
The average production cost (per egg) & $1,103.558$ & $1,017.375$ & 906.786 \\
The average selling price (per egg) & 1,525 & 1,687 & 1,300 \\
Total revenue (IDR) & $21,052,625$ & $16,421,258$ & $8,821,800$ \\
Total cost (IDR) & $15,234,625$ & $9,903,125$ & $6,153,450$ \\
Net return (IDR) & $5,818,000$ & $6,518,133$ & $2,668,350$ \\
\hline
\end{tabular}

Table 6. Value of Input to Output (Returns) in Duck Egg Production in Central Java, Indonesia

\begin{tabular}{|c|c|c|c|}
\hline Items & Tegal & Brebes & Pemalang \\
\hline Input (IDR) & $15,234,625$ & $9,903,125$ & $6,153,450$ \\
\hline Output (IDR) & $21,052,625$ & $16,421,258$ & $8,821,800$ \\
\hline Ratio & $1: 1.382$ & $1: 1.658$ & $1: 1.433$ \\
\hline
\end{tabular}

not optimal yet (Sumekar et al., 2013).

Considering the average marginal efficiency in this study, it is suggested that in order to support the productivity and development of duck business, the institutional factor of duck business is also very important for duck farmers to consider. In Indonesia itself, the Government through the Republic of Indonesia Presidential Regulation Number 98 of 2014 concerning Licenses for Micro and Small Businesses explains that to encourage regional economic growth empowerment for SMEs is needed through granting permits to micro and small business persons. Licensing for SMEs is called a Micro and Small Business Permit (IUMK). Duck business carried out by farmers is strongly recommended to be legalized with a business permit, so that the legal position is stronger. There are several benefits to the legalization of SMEs, including the ease of establishing cooperation, the strength of legal, tax awareness, easy access to capital, business location protection, and assistance and development assistance for SMEs who have IUKM permits. Aside from business legality, institution strengthening can also be done by establishing legal livestock groups that have business licenses, so that they can be used to strengthen the promotion and distribution channels, and can also apply for grants provided by the government to support capital needed for business development (Budiwati, 2017). Supported by various improvements in terms of productivity and institutional development as previously explained, duck business in Central Java is expected to be able to develop and perform more optimally. It is also hoped that this will increase income and lead to an increase in the welfare of the farmers.

\section{CONCLUSION}

This study elaborates the present situations in duck egg production based on a comparative economic analysis across regencies in Central Java, Indonesia. Economic analysis of laying duck business which is discussed in this paper includes: marginal production costs, total net income and input-output ratio of duck egg production. Most farmers involved in the smallhorders duck farm industry are seasoned farmers of small and medium production scale. Despite the low level of education, these farmers gained essential skills 
over the course of experiences. They also selffund their farm business without additional credit loan. Furthermore, the three regencies, which are Tegal, Brebes, and Pemalang demonstrated lucrative performance in net returns and investment returns, although marginal compared to other industries.

\section{ACKNOWLEDGEMENTS}

The authors would like to extend the gratitude to the Ministry of Research, Technology and Higher Education of Republic Indonesian for the financial support through Basic Research 2019 Contract Number 176/SP2H/LT/DRPM/2019.

\section{REFERENCES}

Abdurofi, I., M. M. Ismail, H. A. W. Kamal and B. H. Gabdo. 2017. Economic analysis of broiler production in Peninsular Malaysia. International Food Res. J. 24(2):761-766.

Adepoju, A.A. 2008. Technical efficiency of egg Production in Osun State Nigeria. Int. J. Agric. Econ. Rural Dev. 1(1):1-9.

Ahmad, S., Z. C. Tahir, and A. Ikram. 2008. Economic analysis of poultry production in Mirpur, Azad Jammu Kashmir. Pakistan J. Life Soc. Sci. 6(1):4-9.

Budiwati, S. 2017. People's Business Credit and Legalization in the Micro and Small Business Sector (Kredit Usaha Rakyat (KUR) dan Perizinan di Sektor Usaha Mikro dan Kecil (IUMK). Proceedings of the National Seminar "Legalization as an Instrument to Increase Community Welfare in the Era of Industrialization (Citizen Friendly)". Maret, 2017 UMS, Surakarta, Indonesia: 142-156.

Chanjula, P. and K. Pattamarakha. 2002. Betong chicken raising in Southen Thailand: a preliminary survey. J. Int. Society for Southeast Asian Agric. Sci. (ISSAAS). $8(2): 14-24$.

Directorate General of Animal Husbandry and Health. 2017. Livestock and Animal Health Statistics. Available in: http://www.ditjennak.pertanian.go.id.

Retrieved on 10-03-2019

Elsedig, E. A., M.M. Ismail, and F. M Arshad.2015. Assessing the competitiveness and comparative advantage of broiler production in Johor using policy analysis matrix. Int. Food Res. J.
22(1):116-121.

Ezeibe, A.B.C., E. C. Okorji, J. M.Chah, and R.N.Abudei, 2014. Impact of entrepreneurship training on rural poultry farmers adoption of improved management practices in Enugu State, Nigeria. African J. Agric. Res. 9(20):1604-1609.

Farooq, M. M. M. and A. Asghar. 2001. A factor affecting cost of production and net profit per broiler in subtropics. Livest. Res. Rural Dev. 13(1):1-5.

García-Teruel, J.P. and Martínez-Solano, P. 2007. Effects of working capital management on SME profitability. Int. J Manag. Finance. 3(2):164-177.

Heady, E. and J. Dhillon. 1988. Agriculture production function. Kalyani Publishers. New Delhi, India.

Ismoyowati and Suswoyo, I. 2011. Duck Egg Production and Farmers' Income under Extensive and Intensive Systems in Agricultural and Fishery Center (Produksi Telur dan Pendapatan Peternak Itik pada Pemeliharaan Secara Gembala danTerkurung di Daerah Pertanian dan Perikanan). Jurnal Pembangunan Pedesaan. 11(1):45-54.

Jaggi, S. 2012. Descriptive statistics and exploratory data analysis.Indian Agricultural Statistics Research Institute, Library Avenue. New Delhi, Library Avenue.

Khair, S.M. 2002. Cost of production and constraints of broiler production in Pishin, Balochistan. Pakistan J. Life Soc. Sci. 3(2):43-47.

Nguyen, T. D. N., T. T. H. Nguyen, and G. H. Phung, G. H. 2011. Enhancing coordination in chicken production in Yen the District, BacGiang province, Vietnam. J. ISSAAS. 17(2):104-116.

Patil S, Aditya and A.K. Jha, 2016. Role of financial agencies in integrating small farmers into a sustainable value chain: a synthesis-based on successful value chain financing efforts. Current Sci. 110:20822090.

Rahman, M. S. 2003. Prospects and problems of broiler enterprise under contract farming system with particular reference to marketing practices. J. Biolog. Sci. 6(12):1077-1084.

Sahzadi, T. M. S., U.E. Kalsoom, and K. Shahzad. 2006. Growth performance and feed 
conversion ratio (FCR) of hybrid fingerlings fed on cottonseed meal, sunflower meal and bone meal. Pakistan Vet. J. 26:163-166.

Shamsudin, M. N. 2013. Food security and policy responses with special reference to the poultry industry. Proceeding of WPSA and WVPA Scientific Conference. Faculty of Veterinary UPM, Selangor, Malaysia.

Sumekar, W., Isbandi, U. Atmomarsono and I.
Susilowati.2013. Business performance of duck farmers in brebes regency Central Java. J. Indonesian Trop. Anim. Agric. 38(3):171-175.

Tangendjaja, B. 2013. How to feed broiler for maximum profitability. Proceeding of WPSA and WVPA Scientific Conference. Faculty of Veterinary UPM, Selangor, Malaysia, Nov 30-Dec 1, 2013. 